\section{VILNIUS TECH}

Vilniaus Gedimino

technikos universitetas

\section{APLINKOS APSAUGOS INŽINERIJA / \\ ENVIRONMENTAL PROTECTION ENGINEERING}

$2021 \mathrm{~m}$. kovo 19 d. Vilnius, Lietuva

19 March 2021, Vilnius, Lithuania

ISSN 2029-7157

elSSN 2029-7149

ISBN 978-609-476-270-3

eISBN 978-609-476-271-0

http://jmk.aainz.vgtu.It

https://doi.org/10.3846/aainz.2021.03

\title{
REVIEW OF ORGANIC RANKINE CYCLE HEAT RECOVERY TECHNOLOGIES APPLICATION FOR MARINE DIESEL ENGINES
}

\author{
Tomas Čepaitis ${ }^{1}$, Sergejus Lebedevas ${ }^{2}$ \\ Department of Marine Engineering, Faculty of Marine Technologies and Natural Sciences, Klaipeda University \\ El.p. ${ }^{1}$ tomas.cep7@gmail.com; ${ }^{2}$ sergejus.lebedevas@ku.lt
}

\begin{abstract}
CO}_{2}$ emissions from international shipping could increase between 50-250\% by 2050 year. The EEDI (Energy Efficiency Design Index) is a key requirement for regulating $\mathrm{CO}_{2}$ emissions of maritime transport; a requirement was introduced in 2011 by the International Maritime Organization and came into force gradually. In recent studies it was investigated that no other technologies have the potential and reserves compared to Cogeneration systems. The article provides a short review of ship energy efficiency design index improving technologies and cogeneration systems application for maritime transport which have direct relation with $\mathrm{CO}_{2}$ emissions. A brief comparative analysis of cogeneration cycles is provided also.
\end{abstract}

Keywords: EEDI, waste heat, cogeneration, energy efficiency, decarbonization.

\section{Introduction}

Greenhouse gases (GHG) are becoming more and more increasingly dangerous to the global climate. In 2015, the 2030 Agenda for Sustainable Development and its 17 Sustainable Development Goals (SDGs) were adopted by all UN member 193 countries because greenhouse gas emissions are getting at their highest levels in history (International Maritime Organization, 2014b; Intergovernmental Panel on Climate Change, 2014; International Maritime Organization, 1997). A significant part of these emissions takes the transport sector which contributed $29 \%$ of global $\mathrm{CO}_{2}$ in 2016 as almost all transportation energy is provided by petroleum-based fuels, gasoline and diesel. International shipping takes part of approximately $11 \%$ of transport sector emissions and it is expected to increase in the future as about $90 \%$ of world trade is carried by sea (International Maritime Organization, 2016, 2014b; International Chamber of Shipping, 2015; European Commission, 2014). Generally shipping is the most environmentally friendly in the transport sector in terms of $\mathrm{CO}_{2}$ produced per metric ton of freight and per km of transportation (World Shipping Council, 2009). However, the fact that maritime transport is getting more and more energy efficient, shipping is still a big factor of global greenhouse gas (GHG) emissions which contributes around 940 million tons of $\mathrm{CO}_{2}$ annually. The IMO third greenhouse gas emission study envisions that even with predicted increase in ship average efficiency of $40 \%$ and without any further regulations, $\mathrm{CO}_{2}$ emissions from international shipping could increase between 50-250\% by 2050 (International Maritime Organization, 2014b). The aim of this publication is to review $\mathrm{CO}_{2}$ emission reduction technologies of maritime transport, introduce heat recovery systems with cogeneration cycles and compare their practical application based on recent studies.

\section{Potential technical solutions}

At 2011 July, Marine Environment Protection Committee introduced Energy Efficiency Design Index (EEDI) requirement which was implemented in 2013 January $1^{\text {st }}$ and will be stringent by three phases every 5 years starting from 2015 (Transport \& Enviroment, 2017). This requirement implementation estimates of potentially reduce $\mathrm{CO}_{2}$ emissions from $10 \%$ to $50 \%$ per transport work. Basically EEDI requirement regulates $\mathrm{CO}_{2}$ reduction level for the majority new ship types depending on their size. Complex EEDI calculation formula if simplified in words consists of engines parameters and innova-

(C) 2021 Tomas Čepaitis, Sergejus Lebedevas. Published by Vilnius Gediminas Technical University. This is an Open Access article distributed under the terms of the Creative Commons Attribution License (CC BY 4.0), which permits unrestricted use, distribution, and reproduction in any medium, provided the original author and source are credited. 
tive technologies expressed in grams of $\mathrm{CO}_{2}$ per ships capacity-mile. In short terms, improving ship's EEDI, $\mathrm{CO}_{2}$ emissions are reduced (International Maritime Organization, 2014a, Annex 5, Resolution MEPC.245(66); Devanney, 2010). These regulation factors made ship owners to meet the requirements and approach reducing fuel consumption. There are multiple solutions for fuel saving divided to operational measures (voyage execution, engine monitoring reduction of auxiliary power, weather routing, hull/propeller polishing, trim/draft optimization, slow steaming and etc.) and design measures (more efficient engines, propellers, hull design improvements, wind propulsion). Also, there are innovative technologies as wind and solar power utilization which are not commonly used due to limitations of specific ship type, space deficiency and inconsistent conditions (Nyanya \& Vu, 2019; Quoilin et al., 2013).

Energy efficiency guidance was published from class societies and industrial manufacturers. In example, DNV GL included these measures for energy efficiency improvements:

- Hull form optimization;

- Propulsion efficiency devices;

- New materials (lighter weight);

- Anti-fouling and coating of the hull to prevent drag increasing over time;

- Waste heat recovery;

- Auxiliary engine economizer;

- Main engine tuning;

- Electrification of the ship and switching to DC grid;

- Speed optimization.

The most common way in 2014 was slow steaming, cleaning hub and propeller (Tezdogan et al., 2015) but it led to longer payback period of investments costs. Recent several studies, reports and papers conclude that none of mentioned measures could have effective potential to the utilization of waste heat recovery systems as the main energy (approximately 50\%) is wasted through exhaust gases and cooling when no heat utilization system is used (International Maritime Organization, 2011; Det Norske Veritas, 2012, 2015; Bombarda et al., 2010; Ančić et al., 2014; Ančić \& Šestan, 2015; El Geneidy et al., 2017; Ito \& Akagi, 1986; Schmid, 2004). Great fuel saving opportunities in ships is hidden in the utilization of the exhaust gas heat of internal combustion engines and gas turbine units. Exhaust gas temperatures of various type marine engines are between $260-450^{\circ} \mathrm{C}$. This makes it possible to receive such amount of steam in utilization steam boilers that it would be possible to use it to increase energy efficiency up to $10 \%$ and to provide household consumer needs of heat and electricity as a pair (Mollenhauer \& Tschöke, 2010; Hon \& Wang, 2011).

\section{Waste heat recovery systems}

WHRS and innovation technologies were described as one of the most efficient ways of energy efficiency improvement in the machinery department as it can be used in parallel with other technologies as hull and propulsion optimization and reduce emission up to $14 \%$ (Wärtsilä, 2009; Guangrong, 2017; Bouman et al., 2017; Gilbert et al., 2015; Lindstad \& Eskeland, 2015; Rehmatulla et al., 2017; Larsen et al., 2014a; Mansoury et al., 2018).

Modern diesel engines have up to $50 \%$ efficiency of total fuel energy supplied and other $50 \%$ is lost to surrounding as heat losses (MAN Diesel \& Turbo, 2008). All this energy is lost through exhaust gases, cooling circuit, lubrication circuit, radiation due this fact efficiency waste heat recovery systems (WHRS) were implemented to save fuel. This waste heat is unused energy resource and WHRS can utilize the big part of remaining wasted heat for producing electrical and mechanical useful power that can be used additionally for propulsion and auxiliary need without additional fuel (MAN Diesel \& Turbo, 2009). Well known marine machinery manufacturers offer multiple waste heat recovery systems (WHRS) and are available commercially (Wärtsilä, MAN, Dresser Rand, MHI-Mitsubishi Heavy Industries, Siemens). They can be equipped with a steam turbine (powered by the exhaust gas boilers) and/or a gas turbine (fuelled bypassing a part of the exhaust gas from the turbochargers of the main diesel engines) for electric or mechanical surplus power generation (Schmid et al., 2004). For example, MAN B\&W Diesel turbo offers several WHRS, it is possible to choose between following systems by MAN (MAN Diesel \& Turbo, 2014):

- ST-PT - Steam Turbine-Power Turbine generator unit (Power turbine, steam turbine, gear and generator unit with single or dual pressure steam turbine);

- STG - Steam Turbine Generator unit (Steam turbine, gear and generator unit, single or Dual steam pressure);

- PTG - Power Turbine Generator unit (Power turbine, gear and generator unit). 
Part of the exhaust gas flow is by-passed the main engine turbocharger through gas bypass. As a result, the total amount of intake air and exhaust gas is reduced. The reduction of the intake air amount and the exhaust gas amount results in an increased exhaust gas temperature after the main engine turbocharger(s) and exhaust gas bypass. This means an increase in the maximum obtainable steam production power for the exhaust gas fired boiler - steam, which can be used in a steam turbine for electricity production, but steam amount for domestic use decreases. Also, the revised pressure drop in the exhaust gas bypass, which is part of the WHRS, can be utilised to produce electricity by applying a power turbine (MAN Diesel \& Turbo, 2014). The main WHRS principles are shown in Figure 1. Working fluid is heated in the exhaust gas boiler; working fluid (steam) expands in the turbine where which provides power. MAN Energy solutions states recovery rate up to $12 \%$ of the main engine power can be achieved and fuel reduction of $4-11 \%$ is possible.

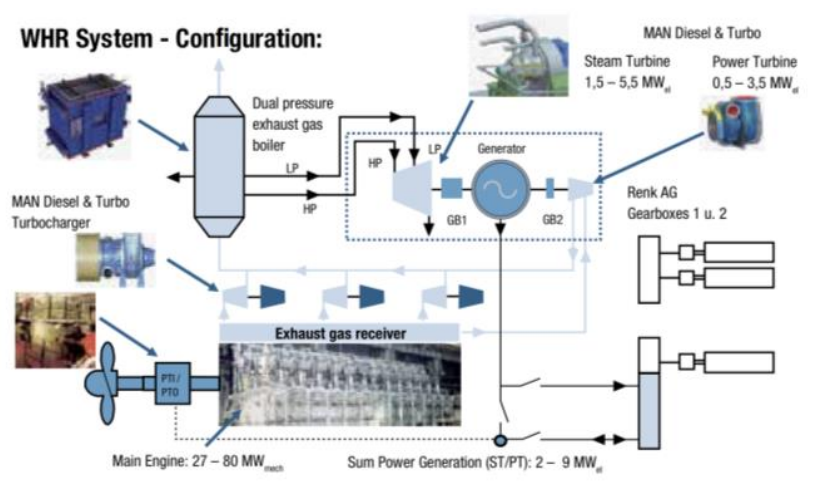

Figure 1. MAN B\&W Waste heat recovery system principles

Another well-known marine machinery manufacturer "Wartsila" system called the Marine Engine Combined Cycle' (ECC) is based on Organic Rankine Cycle (ORC), which recovers exhaust gas and jacket water waste heat, was developed by Turboden and Wartsila cooperation, and it was asserted that system would increase the main engine power from $8 \%$ to $12 \%$ and save up to $17 \%$ of total energy (Yadav et al., 2010). The integration of ECC into ship main engine is shown in Figure 2. Working fluid is heated by the exhaust gas from the main engine in the boiler; fluid evaporates and expands in the turbine where power is created through generator. Further fluid is condensed and goes to the pump and the cycle repeats.

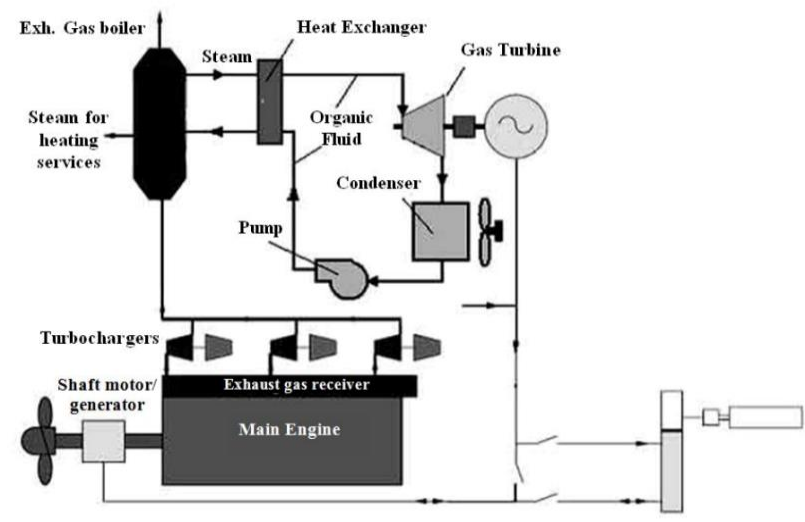

Figure 2. Wartsila \& Turboden developed ECC system integration with ship engine

Wartsila plants are designed to run on a wide range of liquid, gaseous fuels and bio fuels while securing low emissions and high efficiency.

\section{Cogeneration cycles}

Comparative analysis of a commonly used cogeneration cycles are reviewed for maritime application (Noor et al., 2015). There are several ways to recover waste heat energy produced by diesel engine on board of ships, most widely used effective cogeneration cycles are Brayton, Kalina, Rankine.

The Brayton cycle is a constant-pressure cycle typical of gas turbine (GT) engines to produce mechanical power (basis of the jet engine and others). Brayton cycle consists of a heat exchanger to recover the exhaust heat, a turbocharger system to compress air and convert the heat energy into mechanical work and an electric generator integrated into the turbocharger shaft to generate electric power (Liu et al., 2016). Basic Brayton closed cycle scheme is presented in Figure 3. The working fluid is compressed in the compressor and further it enters recuperator where heat content of the turbine exhaust is regenerated. After regeneration working fluid goes through the heat source where achieves the highest temperature in the cycle expansion in the turbine is performed which provides power for compressor and generator. Exhaust from turbine is used to preheat working fluid in recuperator after that heat is eliminated and working fluid cooled to primary conditions (Olumayegun, 2017; Deng et al., 2017). Gas turbine are often used in Navy ship due to the compact size and part load operating mode but are complex in maintenance and high price, therefore it is not commonly used in international shipping (Kuo \& Shu, 
1979; Budiyanto \& Nawara, 2020). Sharma et al. researched WHRS using Brayton supercritical carbon dioxide regenerative recompression cycle and the results showed that overall efficiency of the system improved by $10 \%$ (Sharma et al., 2017).

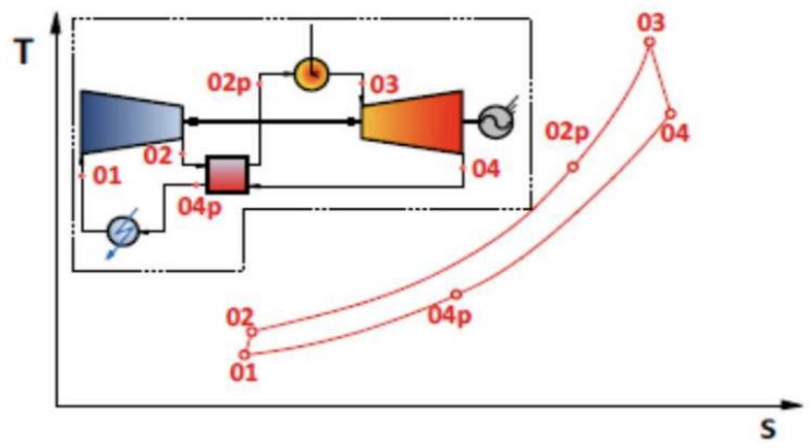

Figure 3. Brayton closed cycle gas turbine

The Kalina cycle is a new concept in heat recovery and power generation, which uses a mixture of $70 \%$ ammonia-30\% water (proposed by Dr. Alexander Kalina in 1983). It is modified form Rankine cycle. In Figure 4 Kalina cycle with reheat process is shown.

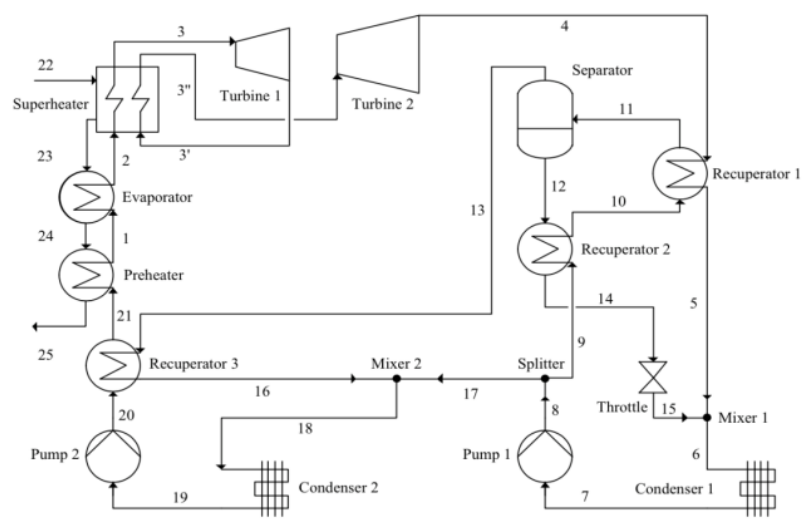

Figure 4. Kalina cycle process

"The pre-heated working fluid (1) is evaporated and superheated in the boiler and then enters the turbine (3). Outlet Stream from turbine is heated in the boiler 3" and it enters the second turbine. From the second turbine working fluid stream enters recuperator where the heat is transferred to another stream 10. Afterwards, recuperator stream (5) is mixed with an ammonia lean stream from the separator (15) to form a leaner solution. This solution is condensed (7) and after being pumped to an intermediate pressure level, the stream (8) is divided in two streams (9) and (17). The stream (9) is heated in Recuperator
(2) and in recuperator (1) to partially evaporated state. It then enters the separator which separates the stream into lean liquid (12) and very rich vapour (13). Heat from stream (13) is used to preheat stream (20) in Recuperator (3) and the stream (16) is then mixed with a leaner solution (17) to form the working solution (18). Finally, the stream is condensed and pumped to the boiler pressure (Larsen et al., 2014b).

Bombarda et al. (2010) in his research of Kalina cycle and ORC comparison for marine diesel engines stated that both cycles produce equal amount of power output, but the Kalina cycle requires very high maximum pressure for high thermodynamic performance and expensive no-corrosion materials as water-ammonia working fluid is used. Researches on the Kalina cycle for marine application is currently ongoing ( $\mathrm{Li}$ et al., 2013; Bombarda et al., 2010).

Organic Rankine Cycle (ORC) is similar to a traditional steam Rankine cycle but uses an organic fluid like hydrocarbon or refrigerant as the working fluid. It is a closed loop thermodynamic cycle that consists of following processes (see Figure 5). Working fluid compressed in the pump and fed to the heat exchanger (1-2), where heat working fluid is evaporated by the exhaust gas heat (2-3). Evaporated working fluid expands in the turbine (4-5) which is mechanically connected by shaft to the generator and mechanical power is created. Further goes heat rejection/condensation stage where working fluid is cooled and condensed (5-6) and the cycle repeats.

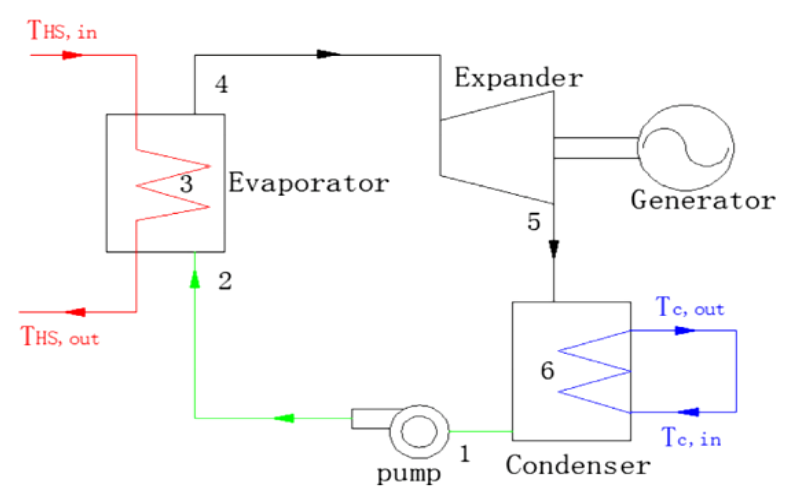

Figure 5. ORC working diagram

ORC makes possible to realize energy recovery from a low temperature heat source. Organic refrigerants or hydrocarbon compounds are used as a working fluid because of the significantly lower boiling point then water as result less input required to produce power (Tchanche et al., 2011; Bao \& Zhao, 2013; Kim \& Kim, 
2017). Kaiko et al. compared ORC and Brayton cycles with marine application and researched that Brayton power output has increased more at high exhaust gas temperatures than ORC, as a result ORC is better in power generation at temperatures up to $680{ }^{\circ} \mathrm{C}$, while Brayton cycle is better at higher temperatures, which makes is less attractive for marine application (Kaikko et al., 2019).

System efficiency can be optimized by selecting a proper working fluid operated at suitable working conditions to achieve maximum energy performance. Hung et al. researched eleven ORC working fluids and their thermodynamic performance, under investigation it was seen that suitable working conditions of various fluids can be identified based on their saturation vapour curves and response to the temperature energy source (Hung et al., 2010). Song et al. examined waste heat recovery with ORC of $996 \mathrm{~kW}$ marine diesel engine and achieved results that configuration is able to reach $10.2 \%$ power increase (Song et al., 2015). ORC most extensively studied cycle for marine application and as a result there is already applied in practice four in-service ships (Opcon Energy Systems AB, 2012; Viking Line, 2014; Marine Log, 2016; Kobelco Binary Cycle Power, 2019; Enogia Efficient Ship, 2019; Orcan Energy AG, 2019) (see Table 1). In service vessel with ORC heat recovery systems showed that fuel saving can be achieved from 4 to $15 \%$ which prompts to quick payback time of the system.

Table 1. List of Organic Rankine Cycle plants used in maritime transport

\begin{tabular}{cccc}
\hline $\begin{array}{c}\text { Ship Name } \\
\text { (Year) }\end{array}$ & $\begin{array}{c}\text { MV Figaro } \\
(\mathbf{2 0 1 2 )}\end{array}$ & $\begin{array}{c}\text { Viking Grace } \\
\mathbf{( 2 0 1 5 )}\end{array}$ & $\begin{array}{c}\text { Arnold Maersk } \\
\mathbf{( 2 0 1 6 )}\end{array}$ \\
\hline Vessel type & PCTC & Cruise Ferry & Container \\
ORC Maker & Opcon & Climeon & Calnetix \\
Capacity & $500 \mathrm{~kW}$ & $150 \mathrm{~kW}$ & $125 \mathrm{~kW}$ \\
Expander type & Twin-screw & Turbine & Radial turbine \\
Fuel savings & $4-6 \%$ & Up to 5\% & Up to 10-15\% \\
\hline \hline & & Orizzonte & Panerai I \& II \\
& Asahi Maru (2017) & (2017) & $\mathbf{( 2 0 1 8 )}$ \\
\cline { 2 - 4 } & & Fishing Vessel & Fast ferry \\
& Kobe Steel & Enogia & Orcan Energy \\
& $125 \mathrm{~kW}$ & $4.8 \mathrm{~kW}$ & $154 \mathrm{~kW}$ \\
& Semi-hermetic screw & Microturbine & Screw \\
& $3 \%$ & $5 \%$ & $6-9 \%$ \\
\hline \hline
\end{tabular}

ORC already taken place in marine application, however not all aspects of practical application were investigated. Recent researches of ORC application are based on determined type marine diesel engines (mainly large, low speed engines) of the research where flexibility of this system application for various engine types in wide speed range and various working fluid is not discussed (Song et al., 2015; Lion et al., 2019; Yang, 2018;
Yang \& Yeh, 2015; Mondejar et al., 2018; Nawi et al., 2019). Currently Authors are preparing such research of parametric and comparative analysis of cogeneration cycles for marine plants, which will include selection of cycle and working fluid according vessel type, engine type and load mode. Theoretical modelling of cycle has been performed with thermal engineering software Thermoflow, which allows accurately simulate thermodynamic performance of the modelled cycle.

\section{Conclusions}

Energy efficiency Design Index improvements has direct connection with $\mathrm{CO}_{2}$ emissions from marine transport, improving this design parameter $\mathrm{CO}_{2}$ emissions reduced accordingly. Waste heat recovery technology systems have more potential than other technologies due to the fact of combustion engine efficiency and wasted heat through exhaust gases. Organic Rankine cogeneration cycle has most attractive practical application for maritime transport compared to the Kalina and Brayton cycles. ORC and Kalina cycles are with a similar level of efficiency but Kalina cycle requirements are less attractive for marine application and Brayton cycle is efficient only at high temperatures. To achieve maximum efficiency of cogeneration cycles, selection of the fluid is required at variable operation conditions of marine transport. The authors of this study failed to find relevant researches of cogeneration cycle with practical selection guidelines for different types and sizes marine diesel engines in different power load modes with various selection of working fluids, therefore, due to the above mentioned fact the comparative studies of parametric analysis results are required for further studies with thermal engineering software in e.g. Thermoflow, to provide basics and guidelines of choosing cogeneration cycle according proper working conditions and parameters of the vessel.

\section{Acknowledgements}

The authors are grateful to collegues of VILNIUS TECH for opportunity to provide our material readers through their journal.

\section{References}

Ančić, I., \& Šestan, A. (2015). Influence of the required EEDI reduction factor on the $\mathrm{CO}_{2}$ emission from bulk carriers. Energy Policy, 84, 107-116. https://doi.org/10.1016/j.enpol.2015.04.031

Ančić, I., Šestan, A., Vladimir, N., \& Klisarić, V. (2014, September 24-25). Influence of new power sources on the 
Attained EEDI [Conference presentation]. Proceedings of the International Conference on Influence on Ship Design, London, UK.

Bao, J., \& Zhao, L. (2013). A review of working fluid and expander selections for organic Rankine cycle. Renewable and Sustainable Energy Reviews, 24, 325-342. https://doi.org/10.1016/j.rser.2013.03.040

Bombarda, P., Invernizzi, C. M., \& Pietra C. (2010). Heat recovery from Diesel engines: A thermodynamic comparison between Kalina and ORC cycles. Applied Thermal Engineering, 30(2-3), 212-219.

https://doi.org/10.1016/j.applthermaleng.2009.08.006

Bouman, E. A., Lindstad, E., Rialland, A. I., \& Strømman, A. H. (2017). State-of-the-art technologies, measures, and potential for reducing GHG emissions from shipping A review. Transportation Research Part D: Transport and Environment, 52(Part A), 408-421. https://doi.org/10.1016/j.trd.2017.03.022

Budiyanto, M. A., \& Nawara, R. (2020). The optimization of exergoenvironmental factors in the combined gas turbine cycle and carbon dioxide cascade to generate power in LNG tanker ship. Energy Conversion and Management, 205, 112468. https://doi.org/10.1016/j.enconman.2020.112468

Deng, B., Tang, Q., \& Li, M. (2017). Study on the steamassisted Brayton air cycle for exhaust heat recovery of internal combustion engine. Applied Thermal Engineering, $125,714-726$.

https://doi.org/10.1016/j.applthermaleng.2017.07.039

Det Norske Veritas. (2012). Shipping 2020 (Technical report). Norway.

Det Norske Veritas. (2015). Energy management study (Technical report).

https://www.dnv.com/maritime/publications/energymanagement-study.html

Devanney, J. (2010). EEDI, a case study in indirect regulation of $\mathrm{CO}_{2}$. Center for Tankship Excellence.

El Geneidy, R., Otto, K., Ahtila, P., Kujala, P., Sillanpää, K., \& Mäki-Jouppila, T. (2017). Increasing energy efficiency in passenger ships by novel energy conservation measures. Journal of Marine Engineering \& Technology, 4177, 1-14.

Enogia Efficient Ship. (2019). http://www.efficientship.eu/

European Commission. (2014). Transport emissions. Brussels, Belgium.

Gilbert, P., Bows-Larkin, A., Mander, S., \& Walsh, C. (2015). Technologies for the high seas: Meeting the climate challenge. Carbon Management, 5, 447-461. https://doi.org/10.1080/17583004.2015.1013676

Guangrong, Z. (2017). Ship energy efficiency technologies now and the future. VTT Technical Reseach Centre of Finland.

Hon, G., \& Wang, H. (2011). The Energy Efficiency Design Index (EEDI) for new ships. The International Council on Clean Transportation (ICCT), Washington, DC, USA. https://theicct.org/publications/energy-efficiency-designindex-eedi-new-ships

Hung, T. C., Wang, S. K., Kuo, C. H., Pei, B.S., \& Tsai, K. F. (2010). A study of organic working fluids on system efficiency of an ORC using low-drage energy sources. Energy, 35(3), 1403-1411.

https://doi.org/10.1016/j.energy.2009.11.025

Intergovernmental Panel on Climate Change. (2014). Climate change 2014: mitigation of climate change.

https://doi.org/10.1017/CBO9781107415416
International Maritime Organization. (1997). Resolution MEPC.203(62) amendments to the annex of the protocol of 1997 to amend the international convention for the prevention of pollution from ships, 1973, as modified by the protocol of 1978 relating thereto.

https://wwwcdn.imo.org/localresources/en/KnowledgeCentre/I ndexofIMOResolutions/MEPCDocuments/MEPC.203(62).pdf

International Maritime Organization. (2011). Report of the marine environment protection committee on its sixtysecond session (MEPC 62/24). London, UK.

International Maritime Organization. (2014a). Annex 5, Resolution MEPC.245(66), Guidelines on the method of calculation of the attained Energy Efficiency Design Index (EEDI) for new ships. IMO, EU, London, UK.

International Maritime Organization. (2014b). Third IMO GHG study (Executive Summary and Final Report). London, UK.

International Maritime Organization. (2016). Module 1: climate change and the shipping response, IMO Train the Trainer (TTT) course on Energy Efficient Ship Operation. https://wwwcdn.imo.org/localresources/en/OurWork/Environm ent/Documents/Air\%20pollution/M1\%20Climate\%20Change $\% 20$ and $\% 20$ Shipping $\% 20$ -

\%20IMO\%20TTT\%20course\%20presentation\%20final1.pdf

Ito, K., \& Akagi, S. (1986). An optimal planning method for a marine heat and power generation plant by considering its operational problem. Energy Research, 10(1), 75-85. https://doi.org/10.1002/er.4440100109

Kaikko, J., Hunyadi, L., Reunanen, A., \& Larjola, J. (2019). Comparison between air bottoming cycle and organic rankine cycle as bottoming cycle [Dissertation]. Kungl Tekniska Hogskolan, Eskilstuna, Sweden.

Kim, D. Y., \& Kim, Y. T. (2017). Preliminary design and perform- ance analysis of a radial inflow turbine for organic Rankine cycles. Applied Thermal Engineering, 120, 549559. https://doi.org/10.1016/j.applthermaleng.2017.04.020

Kobelco Binary Cycle Power. (2018). Binary cycle power generation system for ships completes sea trials, Kobe Steel to begin sales of the new system in 2019.

http://www.kobelco.co.jp/english/releases/1196609_15581. html

Kuo, S. C., \& Shu, H. T. (1979). Alternative closed-cycle gas turbine system design considerations for ship propulsion applications (Report/Paper No. 78-GT-18).

https://asmedigitalcollection.asme.org/GT/proceedings/GT1 978/79719/V01AT01A018/234241

Larsen, U., Nguyen, T. V., Knudsen, T., \& Haglind, F. (2014a). System analysis and optimisation of a Kalina split-cycle for waste heat recovery on large marine diesel engines. Energy, 64, 484-494. https://doi.org/10.1016/j.energy.2013.10.069

Larsen, U., Sigthorsson, O., \& Haglind, F. (2014b). A comparison of advanced heat recovery power cycles in a combined cycle for large ships. Energy, 74, 260-268. https://doi.org/10.1016/j.energy.2014.06.096

Li, X., Zhang, Q., \& Li, X. (2013). A Kalina cycle with ejector. Energy, 54, 212-219. https://doi.org/10.1016/j.energy.2013.03.040

Lindstad, H., \& Eskeland, G. S. (2015). Low carbon maritime transport: How speed, size and slenderness amounts to substantial capital energy substitution. Transportation Research Part D: Transport and Environment, 41, 244-256. https://doi.org/10.1016/j.trd.2015.10.006

Lion, S., Taccani, R., Vlaskos, I., Scrocco, P., Vouvakos, X., \& Kaiktsis, L. (2019). Thermodynamic analysis of waste heat recovery using Organic Rankine Cycle (ORC) for a two- 
stroke low speed marine Diesel engine in IMO Tier II and Tier III operation. Energy, 183, 48-60.

https://doi.org/10.1016/j.energy.2019.06.123

Liu, X., Gong, G., \& Li, Y. H. (2016). Thermal performance analysis of Brayton cycle with waste heat recovery boiler for diesel engines of offshore oil production facilities. Applied Thermal Engineering, 107, 320-328.

https://doi.org/10.1016/j.applthermaleng.2016.05.066

MAN Diesel \& Turbo. (2008). Exhaust gas emission control today and tomorrow application on MAN B\&W two-stroke marine diesel engines. Copenhagen, Denmark.

MAN Diesel \& Turbo. (2009). Waste Heat Recovery System (WHRS) for reduction of fuel consumption, emissions and EEDI (Technical paper).

https://mandieselturbo.com/docs/librariesprovider6/technica 1-papers/waste-heat-recovery-system.pdf

MAN Diesel \& Turbo. (2014). Thermo efficiency system for reduction of fuel consumption and $\mathrm{CO}_{2}$.

https://www.semanticscholar.org/paper/Thermo-EfficiencySystem-for-Reduction-of-Fueland/d639db5c41d7648ee963eb6e0f856c1b476c5a67

Mansoury, M., Jafarmadar, S., \& Khalilarya, S. (2018). Energy and exergy analyses of a combined cycle Kalina and organic Rankine cycles using waste heat. International Journal of Exergy, 27. https://doi.org/10.1504/IJEX.2018.094601

Marine Log. (2016). Maersk vessel first with new waste heat recovery system.

http://www.marinelog.com/index.php?option=com_k2\&vie $\mathrm{w}=$ item\&id $=10842 \% 253$ Amaersk-vesselfirst-with-newwaste-heat-recovery-system \&Itemid $=231$

Mollenhauer, K., \& Tschöke, H. (2010). Handbook of diesel engines. Springer.

https://doi.org/10.1007/978-3-540-89083-6

Mondejar, M. E., Andreasen, J. G., Pierobon, L., Larsen, U., Thern, M., \& Haglind, F. (2018). A review of the use of organic Rankine cycle power systems for maritime applications. Renewable and Sustainable Energy Reviews, 91, 126151. https://doi.org/10.1016/j.rser.2018.03.074

Nawi, Z. M., Kamarudin, S. K., Sheikh Abdullah, S. R., \& Lam, S. S. (2019). The potential of exhaust waste heat recovery (WHR) from marine diesel engines via organic rankine cycle. Energy, 166, 17-31.

https://doi.org/10.1016/j.energy.2018.10.064

Noor, A. M., Puteh, R. C., Martinez-Botas, R., Rajoo, S., Romagnoli, A., Basheer, Salleh, S. H. S., \& Sah, M. H. M. (2015, November 4-5). Technologies for waste heat energy recovery from internal combustion engine: a review [Conference presentation]. Proceedings of the International Conference on "New Trends in Multidisciplinary Research \& Practice", Istanbul, Turkey.

Nyanya, M. N., \& Vu, H. B. (2019). Wind propulsion optimisation and its integration with solar power [World Maritime University Dissertations].

https://commons.wmu.se/cgi/viewcontent.cgi?article=2182 \&context=all_dissertations

Olumayegun, O. (2017). Study of closed-cycle gas turbine for application to small modular reactors (SMRs) and coalfired power generation through modelling and simulation [PhD thesis]. The University of Sheffield, Faculty of Engineering, Department of Chemical and Biological Engineering.
Opcon Energy Systems AB. (2012). Commissioning and testing of first reference installation of Opcon technology for ships. Stocholm, Sweden.

Orcan Energy AG. (2019). Solutions - Applications. https://www.orcan-energy.com/en/applications-marine.html

Quoilin, S., Van Den Broek, M., Declaye, S., Dewallef, P., \& Lemort, V. (2013). Techno-economic survey of organic rankine cycle (ORC) systems. Renewable and Sustainable Energy Reviews, 22, 168-186. https://doi.org/10.1016/j.rser.2013.01.028

Rehmatulla, N., Calleya, J., \& Smith, T. (2017). The implementation of technical energy efficiency and $\mathrm{CO}_{2}$ emission reduction measures in shipping. Ocean Engineering, 139, 184-197. https://doi.org/10.1016/j.oceaneng.2017.04.029

Schmid, H. (2004, April 28-29). Less emissions through waste heat recovery [Conference presentation]. Proceedings of the Green Ship Technology Conference, London, UK.

Sharma, O. P., Kaushik, S. C., \& Manjunath, K. (2017). Thermodynamic analysis and optimization of a supercritical $\mathrm{CO}_{2}$ regenerative recompression Brayton cycle coupled with a marine gas turbine for shipboard waste heat recovery. Thermal Science and Engineering Progress, 3, 62-74. https://doi.org/10.1016/j.tsep.2017.06.004

Song, J., Song, Y., \& Gu, C. (2015). Thermodynamic and lysis and performance optimization of an Organic Rankine Cycle (ORC) waste heat recovery system for marine diesel engines. Energy, 82, 976-985.

https://doi.org/10.1016/j.energy.2015.01.108

Tchanche, B. F., Lambrinos, G., Frangoudakis, A., \& Papadakis, G. (2011). Low-grade heat conversion into power using organic Rankine cycles - A review of various applications. Renewable and Sustainable Energy Reviews, 15 3963-3979. https://doi.org/10.1016/j.rser.2011.07.024

Tezdogan, T., Demirel, Y. K., Kellett, P., Khorasanchi, M., Incecik, A., \& Turan, O. (2015). Full-scale unsteady RANS CFD simulations of ship behaviour and performance in head seas due to slow steaming. Ocean Engineering, 97, 186206. https://doi.org/10.1016/j.oceaneng.2015.01.011

Transport \& Enviroment. (2017). Statistical analysis of the energy efficiency performance (EEDI) of new ships built in 2013-2017.

https://www.transportenvironment.org/sites/te/files/publicati ons/Statistical\%20analysis\%20of\%20the\%20energy\%20effi ciency $\% 20$ performance $\% 20 \% 28 \mathrm{EEDI} \% 29 \% 20 \mathrm{of} \%$ 20new\% 20ships.pdf

Viking Line. (2014). Viking grace first ship to install new Swedish Heat Recovery System.

https://www.vikingline.com/globalassets/documents/market _specific/corporate/press/pressreleaseeng/2014/20141201climeon-eng.pdf

Wärtsilä. (2009, February 3). Boosting energy efficiency. Energy Efficiency Catalogue / Ship Power R\&D.

https://www.shippingtech.it/PDF/convegni\%202010/2tecnol ogie1/Baan.pdf

World Shipping Council. (2009). The liner shipping industry and carbon emissions policy.

Yadav, N., Khan, I. A., \& Grover, S. (2010). Modeling and analysis of simple open cycle gas turbine using graph networks. World Academy of Science, Engineering and Technology, 39, 843-851.

Yang, M.-H. (2018). Payback period investigation of the organic Rankine cycle with mixed working fluids to recover waste heat from the exhaust gas of a large marine diesel en- 
gine. Energy Conversion and Management, 162, 189-202. https://doi.org/10.1016/j.enconman.2018.02.032

Yang, M.-H., \& Yeh, R.-H. (2015). Thermodynamic and economic performances optimization of an organic Rankine cycle system utilizing exhaust gas of a large marine diesel engine. Applied Energy, 149, 1-12.

https://doi.org/10.1016/j.apenergy.2015.03.083

\section{ORGANINIO „RANKINE“ CIKLO ANTRINÉS \\ ŠILUMOS NAUDOJIMO JŪRINĖS PASKIRTIES DYZELIAMS TECHNOLOGIJOS APŽVALGA}

\author{
T. Čepaitis, S. Lebedevas
}

Santrauka

Tarptautinès laivybos išmetamas $\mathrm{CO}_{2}$ kiekis iki 2050 metų, anot Tarptautinès jūrų organizacijos, didès 50-250\%. $2011 \mathrm{~m}$. ̨̣vestas energijos efektyvumo projektavimo indeksas (EEDI) yra pagrindinis reikalavimas, reguliuojant $\mathrm{CO}_{2}$ emisijų kiekị jūrų transportui, kuris ịsigalioja laipsniškai naujai statomiems laivams. Rengiant laivų projektus šio reikalavimo atitikčiai būtini technologiniai sprendimai. Atliekant naujausius tyrimus teigiama, kad jokios kitos technologijos neturi potencialo, lyginant su kogeneracinèmis sistemomis. Straipsnyje pateikiama trumpa energetikos efektyvumo projektavimo indekso tobulinimo technologiju jūrų transporte apžvalga, kogeneracinių sistemų pritaikymas jūrų transportui mažinant $\mathrm{CO}_{2}$ emisijas. Pateikiama kogeneracinių ciklų lyginamoji analizè.

Reikšminiai žodžiai: EEDI, antrinè šiluma, kogeneracija, energijos efektyvumas, dekarbonizacija. 